\title{
ANALYSIS OF POSSIBILITY OF YEAST PRODUCTION INCREASE AT MAINTAINED CARBON DIOXIDE EMISSION LEVEL
}

\author{
Barbara WŁODARCZYK ${ }^{1}$, Paweł P. WŁODARCZYK \\ Opole University, Opole, Poland
}

\begin{abstract}
Main parameters polluting of technological wastewater (dregs from decantation and thicken of the wort) from yeast industry are: nitrogen, potassium and COD. Such wastewater are utilized mostly on agricultural fields. Unfortunately, these fields can only accept a limited amount of wastes. The basic parameter limiting there the amount of wastewater is nitrogen. When capacity of the production is large sewages are often pretreated at an evaporator station. However, due to the fairly high running costs of the evaporator station currently such a solution is applied only to a small amount of wastes (just to meet legal requirements). Replacement of the earth gas with a biomass being supplied to the evaporator station from the agricultural fields will both allow to maintain the carbon dioxide emission level and enable the production growth. Moreover, the biomass growing on the agricultural fields being fertilized with the wastewater coming from the yeast production allows consequently to utilize the greater volume of wastewater. Theoretically, the possible increase in the yeasts production, with maintaining the carbon dioxide emission level, can reach even $70 \%$. Therefore, the solution presented in this paper combines both intensification of the yeasts production and maintaining the carbon dioxide emission level.
\end{abstract}

Keywords: production increase, renewable energy sources, environmental engineering, technological wastewater treatment, yeast, environmental protection.

1 Corresponding author: Opole University, Faculty of Natural Sciences and Technology, Department of Process Engineering, Dmowskiego St 7-9, 34-365 Opole, e-mail: barbara.wlodarczyk@uni.opole.pl,pawel.wlodarczyk@uni.opole.pl 


\section{INTRODUCTION}

Food industry is the driving force for the economy of Poland. This industry has also become an important partner and competitor for European food producers. Position of polish food industry is very high. In the EU Poland is the sixth producer of food $[8,14,36-40,42]$.

The essential feature of the food industry is a large amount of technological wastewater. For wastewater treatment different methods are used [24, 29]. Most of them are suitable for transformation into raw materials for other technologies [45]. This way we can reduce their negative impact on the environment and use them as a new source of raw materials. An example of such a solution is the yeast industry. Technological wastewater (dregs from decantation and thicken of the wort - process water) from this industry may be used as a fertilizer (e.g. in factory Lesaffre in Wołczyn, analysed in this paper), which causes recovery of macro and micronutrients as well as organic matter [4]. The latter of ones is very important on account of the deficit of an organic matter in the soils of Europe. Industrial wastewater (process water) from the yeast production process may by used directly or as a concentrated fertilizer [3, 17, 23, 28, 41, 46, 47].

Technological wastewater from the yeast industry have not only a high pollutants load but are produced in great amounts as well. The main technology components of polluting effluents are: nitrogen, potassium, total suspension, COD and BOD. Such wastewater are mainly supplied to the agricultural fields $(\mathrm{AF})$. Those fields utilize the wastewater in the plant-soil environment $[2,20$, 35, 49].

The amount of nitrogen is limited by the Regulation of the Minister of Environment [30], however, within the regulation it is possible to control the parameter according to the kinds of plants used on the AF.

Amount of the technological wastewater $D$ those can be utilized in one hectare of the AF depending on the concentration of nitrogen $C_{N}$ may be determined from Eq. $1.1[21]$

$$
D=\frac{Z_{N} \cdot P_{N}}{C_{N} \cdot \eta \cdot R_{N}}\left[\frac{m^{3}}{h a \cdot y e a r}\right]
$$

where:

$D$ - maximum dose of technological wastewater per year per hectare

[ $\mathrm{m}^{3} /$ ha year $]$

$Z_{N}$ - plant demand for nitrogen per year per hectare [ $\mathrm{kgN} / \mathrm{ha} \cdot$ year $]$

$P_{N}$ - indicator of the demand for nitrogen (if agricultural fields are fertilized only by technological wastewater $\mathrm{P}_{\mathrm{N}}=1$ )

$\eta$ - nitrogen utilization factor depending on the irrigation system 
$R_{N}$ - equivalent of nitrogen fertilizer for technological wastewater from yeast production $\left(R_{N}=1\right)$

$C_{N}$ - nitrogen concentration in the technological wastewater $\left[\mathrm{kgN} / \mathrm{m}^{3}\right]$

The above formula is valid also for the other parameters, such as K or TSS. Nonetheless, the main parameter determining the volume of wastewater directed to the field is N. For this reason, further analysis is focused on this very parameter.

Currently, the global trends in the food industry are both to minimize the number of small factories and to establish large factories with a high production potential. A small dispersal of the factories and a growth of their production capacities generates large amounts of sewages formation those should be utilized in the relatively small AF. However, the AF can only accept a strictly limited amount of technological wastewater. The basic parameter determining amount of the wastewater to be utilized in the AF is concentration of nitrogen $C_{N}$, because this element in excess can lead to destruction of the plants $[11,13$, $31,32,33,43,44]$.

Actually in analysed factory (Lesaffre, Wołczyn) when capacity of the production is large wastewater are often pretreated at an evaporator station (ES). However, due to the fairly high running costs of the evaporator station currently such a solution is applied only to a small amount of wastes (just to meet legal requirements). Replacement of the earth gas with a biomass being supplied to the evaporator station from the agricultural fields will both allow to maintain the carbon dioxide emission level and enable the production growth. Moreover, the biomass growing on the agricultural fields being fertilized with the wastewater coming from the yeast production allows consequently to utilize the greater volume of wastewater.

The aim of the work is to demonstrate that by changing the stream of the technological wastewater directed to ES, and thus also increasing the amount directed to $\mathrm{AF}$, it is possible to intensify the production of yeast. In addition, using the AF for growing energy crops, and then using them instead of natural gas to power the $\mathrm{ES}$ it is possible to maintain the level of $\mathrm{CO}_{2}$ emissions despite the increased production.

\section{MATERIAL AND METHODS}

In order to increase the capacity of the yeast production a part of the wastewater stream following out from the third centrifugal separator should be sent to the evaporator station. However, at present, the high running costs of the ES reduce a volume of this part only to the minimal value which enables the fulfillment of the legal requirements in regarding to the amount of the land and water pollutions $[9,12,18,19,30]$. 
The production of the yeasts is determined by the amount of the sewages those can be utilized on the AF (Eq. 2.1) (own compilation).

$$
\dot{N}_{A F}=D \cdot A\left[\frac{m^{3}}{y e a r}\right]
$$

where:

$\dot{N}_{A F}$ - maximum volume of technological wastewater distributed on the agricultural fields $\left[\mathrm{m}^{3} /\right.$ year $]$

A - area of the agricultural fields

However, the value calculated from Eq. 2.1 can be increased by increasing in the value of the part of the sewages being send to the ES. Sewages those are pretreated so far came from the first two steps of the yeast's wort separation. This process takes place in centrifugal separators. Nowadays, the sewages from the third (the last) separator are not being sent to the ES as they contain less pollutants. Nevertheless, directing a certain part of the sewages coming from the third separator to the ES will make possible a further reduction of the all pollutants concentration (also nitrogen) and in consequence of that will increase both the maximum value of sewages distributed on the AF in one year and the capacity of the yeasts production [1]. The value of this part depends on the planned increase of the yeast production.

Scheme of technological wastewater streams was shown in Fig. 1. (developed on the basis of wastewater streams in factory Lesaffre in Wołczyn).

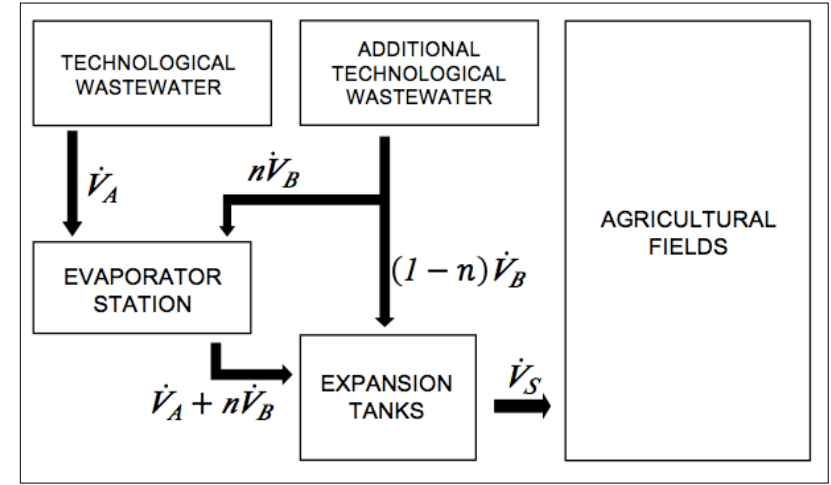

Fig. 1. Additional volume of technological wastewater directed to the evaporation station [own compilation]

Directing an additional stream of the technological wastewater $n \dot{V}_{B}$ to the precleaning in the ES will reduce the concentration of all components. So, it allows to deposit a larger amount of wastewater on AF. What not be possible without 
ES (Fig. 1). The concentration of the individual components (Fig. 1) can be calculated from the following formula [10] (developed on the basis of wastewater streams in analysed factory)

$$
C_{i}=\frac{(1-n) \dot{V}_{B} C_{i B}+\dot{V}_{A} C_{i A}}{\dot{V}_{S}}\left[\frac{k g}{m^{3}}\right]
$$

where:

$n$ - volume fraction of this part of the wastewater flowing from the third separator which is being sent to the ES, $n \in[0,1]$

$C_{i} \quad$ - concentration of the individual components of the technological wastewater directed on agricultural fields $\left[\mathrm{kg} / \mathrm{m}^{3}\right]$

$C_{i A}$ - concentration of the individual components of the technological

wastewater directed to evaporation station $\left[\mathrm{kg} / \mathrm{m}^{3}\right]$

$C_{i B}$ - concentration of the individual components in the additional stream of the technological wastewater directed to the evaporation station $\left[\mathrm{kg} / \mathrm{m}^{3}\right]$

$\dot{V}_{A} \quad$ - stream of the technological wastewater directed to the evaporation station $\left[\mathrm{m}^{3} /\right.$ year $]$

$\dot{V}_{B} \quad$ - additional stream of the technological wastewater directed to the evaporation station $\left[\mathrm{m}^{3} /\right.$ year $]$

$\dot{V}_{S} \quad$ - stream of the technological wastewater directed to the agricultural fields $\left[\mathrm{m}^{3} /\right.$ year $]$

Next the relative increase in the capacity of the yeasts production $\Delta \mathrm{x} / \mathrm{x}_{0}$ for actually for current state of the factory was calculated with the following formula [10]

$$
\frac{\Delta x}{x_{o}}=\frac{n \dot{V}_{B} C_{i B}}{(1-n) \dot{V}_{B} C_{i B}+\dot{V}_{A} C_{i A}}
$$

where:

$$
\frac{\Delta x}{x_{o}} \text { - relative increase of the production }
$$

The next stage was examining the possibility of using biomass to power ES. The cultivation of biomass on the AF belonging to the enterprise allows to reduce the cost of ES use (fuel cost), and also to limit $\mathrm{CO}_{2}$ emissions (it is assumed, that in the biomass combustion process the $\mathrm{CO}_{2}$ emission balance is zero, because in this process the emission level is the same as when absorbing during 
photosynthesis). The increase in the yeast production value without biomass cultivation and also with biomass cultivation was analysed.

\section{RESULTS}

Decrease in the concentration of the sewages components versus the volume fraction $n$ is shown in Fig. 2, (Eq. 2.2) [10].

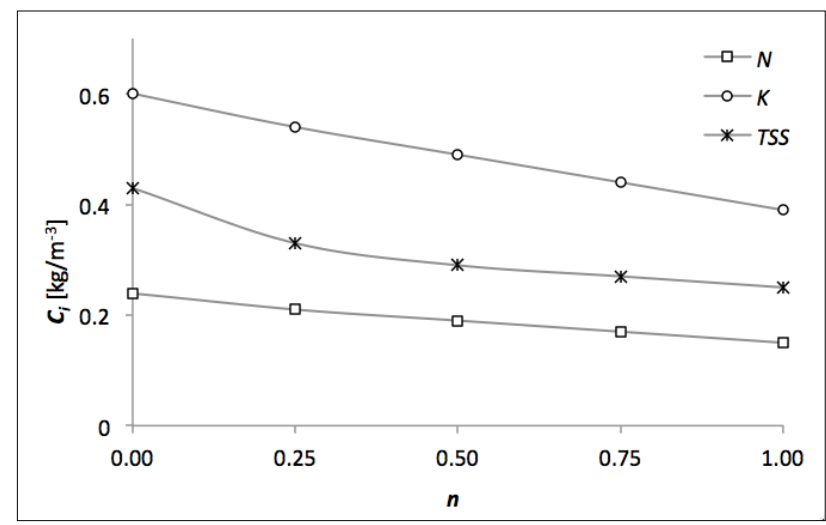

Fig. 2. Decrease in the concentration $C_{i}$ of individual components as the function of $n . N$ - nitrogen, $K$ - potassium, TSS - total suspended solids

Capacity of the yeasts production is determined by the concentration of nitrogen in the sewages those are supplied to the AF. Fig. 2 shows that increase in the volume fraction $n$ causes decrease in the nitrogen concentration $C_{N}$ what, in consequence, makes possible increase in the capacity of the yeasts production. The relative increase in the yeast production $\Delta \mathrm{x} / \mathrm{x}_{0}$ (Eq. 2.3) versus the volume fraction $n$ is shown in Fig. 3 .

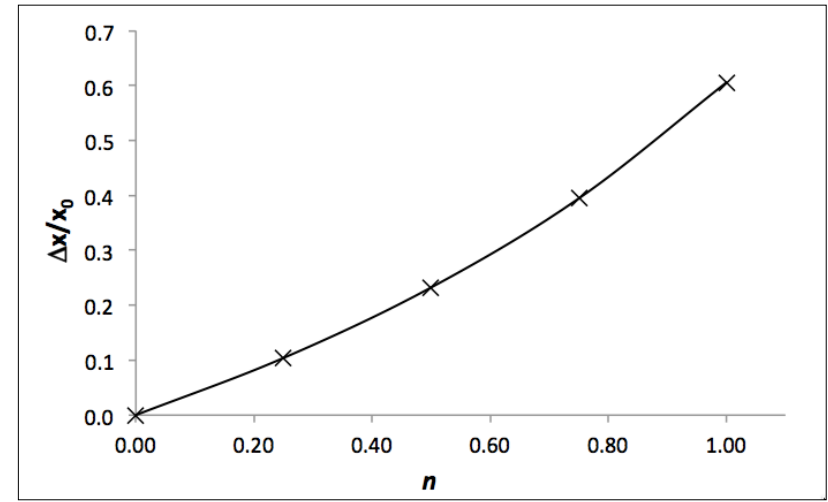

Fig. 3. Relative increase in the yeast production value $\Delta x / x_{0}$ versus the volume fraction $n$ 
Partial replacement of natural gas with biomass in order to supply power to the ES allows to reduce both the $\mathrm{CO}_{2}$ emission and the costs of power generation [5, $22,34,48]$. In addition, the biomass grown in the agricultural fields will be fertilized by the sewages from the yeast production. This allows to increase both the amount of sewages directed to the agricultural fields and the capacity of the yeast production $[6,7,15,16]$.

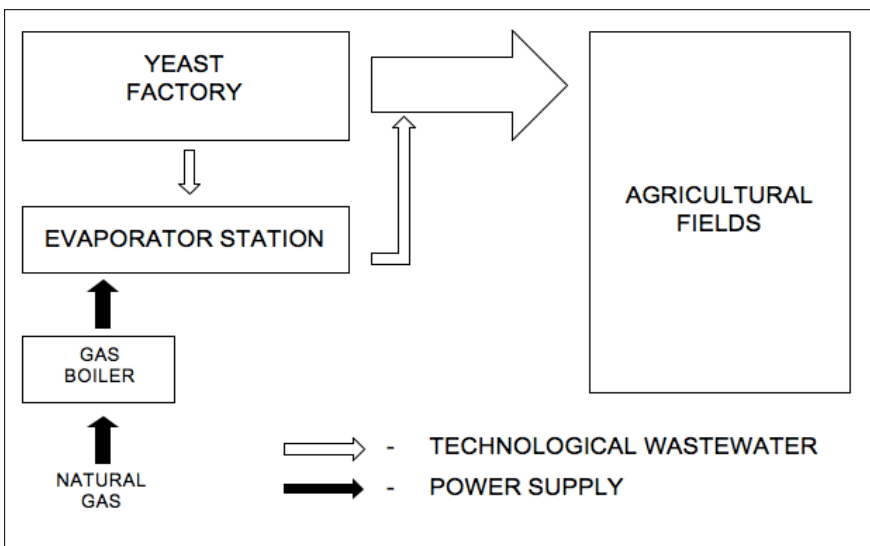

Fig. 4. Actual scheme of the system of the yeast production process [own compilation]

Scheme of the increased participation of the technological sewages directed to the $\mathrm{AF}$ and obtaining biomass (to heat the evaporation station) from the own $\mathrm{AF}$ is shown in Fig. 5.

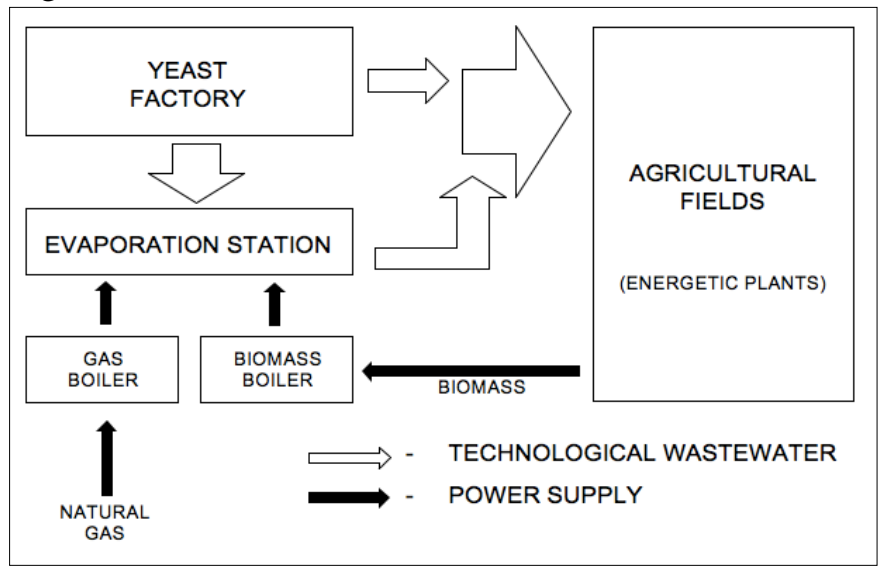

Fig. 5. Proposed scheme of the system of the yeast production process [own compilation] 
The increase in the yeast production value without biomass cultivation and with biomass cultivation is illustrated in Fig. 6. Calculated on the basis of equation 2.3.

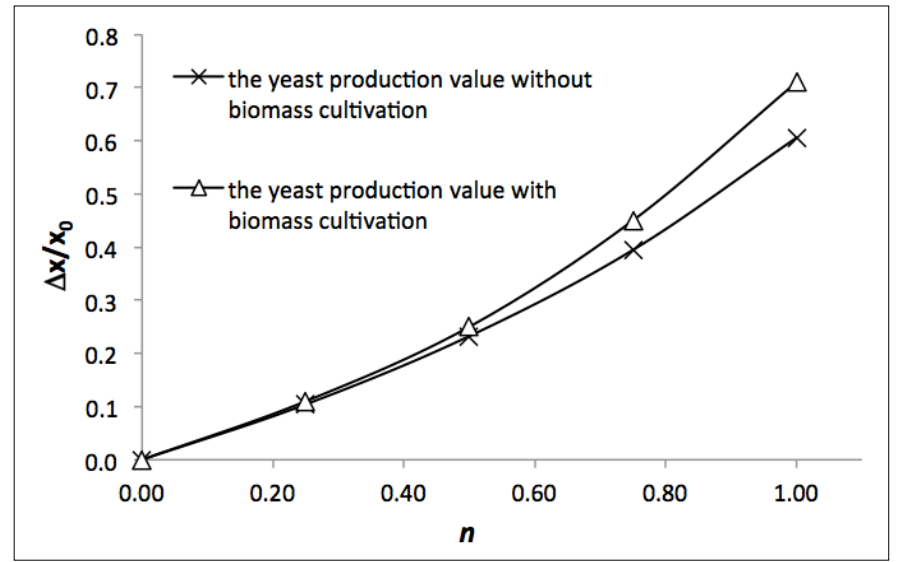

Fig. 6. The relative increase in the yeast production value $\Delta x / x_{0}$ versus the volume fraction $n$ [own compilation]

Moreover, condensate from ES is a valuable organic fertilizer [25-27]. This condensate is sold to individual farmers. Sales of fertilizer provide part of the costs of using the ES. Directing an additional stream of the sewages to the ES simultaneously will enable increase the amount of condensate, so will enable growth provide part of the costs of using the ES.

\section{CONCLUSIONS}

Thanks to directing more wastewater to ES, it is possible to increase the stream directed to AF, by lowering the concentration of pollutants in the wastewater (N, K, and TSS) (fig. 2). While meeting the standards of the Regulations of the Ministry of Environment [30]. The result is an production increase (fig. 3) thanks to the possibility of increasing the amount of wastewater to be deposited on $\mathrm{AF}$.

In order to reduce the cost of use of the ES, it is necessary to use AF to cultivate energy crops (biomass) (fig. 5). In addition, by repalcing the crops cultivated on these fields (currently it is mainly cereals) with energy crops, it is possible to further increase the amount of landfilled waste. Such treatment is possible due to the fact that the demand of energy crops for nitrogen and other components is higher. The result of this is the ability to further increase production (fig. 6). In addition, the biomass from AF directed to supply the ES (instead of natural gas) will contribute to maintaining $\mathrm{CO}_{2}$ emission level despite the increased production. 
The maximum growth of the relative increase in the yeast production value while maintaining the $\mathrm{CO}_{2}$ emission level is at the level of $60 \%$ (fig. 6). However, taking into account that biomass cultivation in the AF will make possible maximum the yeast production increase even of $70 \%$ we may postulate that the solution presented in this paper enables both intensification of the yeast production and maintaining the $\mathrm{CO}_{2}$ emission level (fig. 6). That way the solution presented combines both intensification of yeast production and maintaining the $\mathrm{CO}_{2}$ emission level.

Based on the above analysis of the research results the following conclusions have been formulated:

1. Directing an additional stream of the technological wastewater (process water) to the evaporation station theoretically can causes the relative increase in the capacity of the yeasts production of $60 \%$.

2. Additionally, in the case of cultivation of the energetistic plants on factory's agricultural fields (fertilized of the wastewater) will enable growth of the relative increase of the yeast production even of $70 \%$.

3. The solution presented provides the increase of the production parallel with reduction of the level of $\mathrm{CO}_{2}$ emission.

\section{ADDITIONAL INFORMATION}

This work created during cooperation Opole University and yeast factory Lesaffre S.A. - The project financed by the European Union from the European Social Fund under the Operational Programme Human Capital 2007-2013. The project was realised by Opole University entitled „Współpraca między sektorami szansą na innowacyjność przedsiębiorstw".

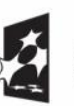
KAPITAt LUDZK
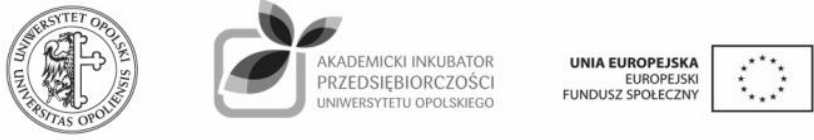

The measurements was conducted during the authors scientific internship in Lesaffre S.A.

\section{REFERENCES}

1. Aparicio I., Santos J. L., Alonso E.: Limitation of the concentration of organic pollutants in sewage sludge for agricultural purposes, Waste Management, 29 (5) (2009) pp. 1747-1753.

2. Brendecke J.: Axelson R., Pepper I., Soil microbial activity as an indicator of soil fertility: Long-term effects of municipal sewage sludge on an arid soil, Soil Biology and Biochemistry, 25 (6) (1993) pp. 751-758. 
3. Csuk R., Glanzer B.I.: Baker's yeast mediated transformations in organic chemistry. Chem. Rev., 91 (1) (1991) pp. 49-97.

4. Czyżyk F. (red.): Wytyczne w zakresie wykorzystania produktów ubocznych oraz zalecanego postępowania $z$ odpadami $w$ rolnictwie i przemyśle rolnospożywczym, Ministerstwo Rolnictwa i Rozwoju Wsi Instytut, Technologiczno-Przyrodniczy, Falenty 2010.

5. Directive 2009/28/EC of the European Parliament and of the Council of 23 April 2009 on the promotion of the use of energy from renewable sources and amending and subsequently repealing Directives 2001/77/EC and 2003/30/EC.

6. Directive 2001/77/EC of European Parliament and of the Council on the Promotion of Electricity Produced from Renewable Energy Sources in the Internal Electicity Market.

7. Directive 2009/28/EC the European Parliament and of the Council of 23 April on the promotion of the use of energy from renewable sources and amending and subsequently repealing Directives 2001/77/EC and 2003/30/EC.

8. Drożdż J.: Inwestycje $w$ przemyśle spożywczym $w$ okresie integrowania $z$ UE, Przemysł Spożywczy, 59 (1) (2005) pp.6-8.

9. Fjaervoll A.: The theory and use of centrifugal machines in the dairy industry, International Journal of Dairy Technology, 21 (4) (1968) pp. 180186.

10. Gawdzik A., Włodarczyk B.: Effects of the industrial wastes purification system on the productivity of the yeast factory Lesaffre in Wolczyn, Environmental Engineering, DOI: 10.3846/enviro.2014.020

11. George S., Larsson G., Olsson K., Enfors S:, Comparison of the Baker's yeast process performance in laboratory and production scale, Bioprocess Enfineering, 18 (1998) pp. 135-142.

12. Hugo E.: Handbook of cane sugar engineering, Elsevier Publ. Comp., New York, 1974.

13. Ifrim G., Bahrim G., Rapeanu G., Nitrogen removal strategy from baker's yeast industry effluens, Innovative Romanian Food Biotechnology, (2) (2008) pp.11-24.

14. Jensen C.: Localized Spillovers in the Polish Food Industry: The Role of FDI in the Development Process, Regional Studies, 38 (5) (2004) pp. 535550.

15. Kaltschmitt M.: Hartmann H.: Energie aus Biomasse: Grundlagen, Techniken und Verfahren, Springer-Verlag 2001.

16. Kamiński J., Leduc G.: Energy efficiency improvement options for the EU food industry, Polityka Energetyczna, IGSMiE PAN, 13 (1) (2010). 
17. Kelling K.A., Keeney D.R, Walsh L.M., Ryan J.A.: A Field Study of the Agricultural Use of Sewage Sludge, Journal of Environmental Quality, 6 (4) (1977) pp. 352-358.

18. Kessler, H. G.: Lebensmttel- und Bioverfahrenstechnik, Molkereitechnologie, Verlag A. Kessler, Munchen 1996.

19. Kessler, H. G.: Food and Bio Process Engineering, Diary Technology, Verlag A. Kessler, Munchen 2002.

20. Kobya M., Delipinar S.: Treatment of the baker's yeast wastewater by electrocoagulation, Journal of Hazardous Materials, 154 (1-3) (2008) pp. 1133-1140.

21. Kutera J.: Wykorzystanie ścieków przemystu spirytusowo- drożdżowego w rolnictwie, Materiały instruktażowe IMUZ (52), Falenty, 1986.

22. Lewandowski W.: Proekologiczne odnawialne źródta energii, Wydawnictwo Naukowo-Techniczne, Warszawa 2007.

23. Manning DAC, Mineral sources of potassium for plant nutrition. A review, Agronomy for Sustainable Development, (2009) pp.281-294 DOI: 10.1051 /agro/ 2009023.

24. Nowak A.J., Królik D., Kostecki J.: Wastewater treatment in constructed wetlands, Civil and Environmental Engineering Reports, 11 (2013) 93-99.

25. Opinia Instytutu Nawożenia i Gleboznawstwa o przydatności nawozu organicznego o nazwie „Vinassa - wywar melasowy” do nawożenia roślin w uprawie polowej i na trwałych użytkach zielonych użytkowanych kośnie, Puławy, 2005.

26. Opinia Państwowego Instytutu Weterynaryjnego dotycząca oddziaływania nawozu organicznego o nazwie „Vinassa - wywar melasowy” na zdrowie zwierząt, po prawidłowym jego zastosowaniu, Puławy, 2005.

27. Opinia Instytutu Medycyny Wsi dotycząca wpływu nawozu organicznego o nazwie „Vinassa - wywar melasowy” na zdrowie ludzi, Lublin, 2005.

28. Pawełczyk A., Górecki H.: Perspektywy utylizacji odpadów rolno spożywczych na nawozy mineralno-organiczne, Chemia dla Rolnictwa, Oficyna Wydawnicza Politechniki Wrocławskiej, (1996) pp.108-113.

29. Płuciennik-Koropczuk E., Sadecka Z.: Myszograj S., COD fractions in raw and mechanically treated wastewater, Civil and Environmental Engineering Reports, 11 (2013) 101-113.

30. Rozporządzenie Ministra Środowiska z dnia 18 listopada 2014r. w sprawie warunków, jakie należy spełniać przy wprowadzaniu ścieków do wód lub ziemi, oraz w sprawie substancji szczególnie szkodliwych dla środowiska wodnego. Na podstawie art. 45 ust. 1 pkt 1,3 i 4 ustawy z dnia 18 lipca 2001 r. Dz. U. z 2012 r. poz. 145, z późn. zm.

31. Sauerbeck D.: Effects of agricultural practices on the physical, chemical and biological properties of soils: part II-use of sewage sludge and 
agricultural wastes, Scientific Basis for Soil Protection in the European Community, Springer, (1987) pp. 181-210.

32. Schnaak W., Küchler Th., Kujawa M., Henscherl K.-P., Süssenbach D., Donau R.: Organic contaminants in sewage sludge and their ecotoxicological significance in the agricultural utilization of sewage sludge, Chemosphere, 35 (1/2) (1997) pp. 5-11.

33. Singh R.P., Agrawal M., Potential benefits and risks of land application of sewage sludge, Waste Management, 28 (2008) pp. 347-358.

34. Special report on carbon dioxide capture and storage, Interngovernmental Panel on Climate Change (IPCC), Cambridge University Press, New York 2005.

35. Thornton I. (scienticic co-ordinator): Pollutants in urban waste water and sawage sludge, Final Report, ICON, London 2001.

36. Urban R.: Polski przemyst spożywczy w pierwszych miesiacach po integracji z Unia Europejska, Warszawa, 2005.

37. Urban R.: Polish market of food and drinks, Przemysł spożywczy, 62 (8) (2008) pp. 26-30.

38. Urban R.: Food industry in the prospect of joining European Union, Przemysł Spożywczy, 54 (6) (2000), pp. 4-7.

39. Urban R., Drożdż J.: Development Tendencies in the Sectors of Bakery and Sugar Confectionery, Przemysł Spożywczy, 56 (6) (2002) pp. 22-27.

40. Urban R.: Developmental tendencies of Polish food industry, Przemysł Spożywczy 61 (8) (2007) pp. 20-25.

41. Walker G.M.: Yeast-physiology and biotechnology, ed. J. Wiley, Chichester, 1998.

42. Walkenhorst P., Determinants of foreign direct investment in the food industry: The case of Poland, Agribusiness, vol. 17 (3) (2001) pp. 383-395.

43. Wang M-J., Land application of sewage sludge in China, Science of The Total Environment, 197 (1-3) (1997) pp. 149-160.

44. Wang X., Chen T., Ge Y., Jia Y., Studies on land application of sewage sludge and its limiting factors, Journal of Hazardous Materials, 160 (2008) pp. 554-558.

45. Włodarczyk, P.P., Włodarczyk, B., Analysis of the possibility of using stainless steel and copper boride alloy as catalyst for microbial fuel cell fuel electrode, Archives of Waste Management and Environmental Protection, 17 (1) (2015) pp. 111-118.

46. Włodarczyk B., Gawdzik A.: Ocena gleb uprawnych na podstawie poziomu substancji nawozowych $w$ wyniku nawożenia nawozem organicznym powstałym z przemystu drożdżowego, Monografia Uniwersytetu Opolskiego, Inżynieria Procesowa w Ochronie Środowiska, (2011) pp. 92-100. 
47. Włodarczyk B., Gawdzik A.: Wykorzystanie biomasy $w$ celu obniżenia kosztów użytkowania stacji wyparnej, Monografia Uniwersytetu Opolskiego, Inżynieria Procesowa w Ochronie Środowiska, (2011) pp. 109115.

48. Wrzosek J., Gworek B.: Biomass as renewable energy source, Ochrona Środowiska i Zasobów Naturalnych, nr 43 (2010) pp. 104-116.

49. Zub S., Kurissoo T., Menert A., Blonskaja V.: Combined biological treatment of high-sulphate wastewater from yeast production, Water and Environment Journal, 22 (4) (2008) pp. 274-286.

\section{ANALIZA MOŻLIWOŚCI ZWIEKSSENIA PRODUKCJI DROŻDŻY PRZY UTRZYMANIU POZIOMU EMISJI DITLENKU WĘGLA}

\section{Streszczenie}

Głównymi parametrami technologicznych ścieków drożdżowych są azot, potas i ChZT. Ścieki te mogą być zagospodarowywane na polach rolniczego wykorzystania, jednak pola te mogą przyjąć tylko ograniczoną ich ilość. Podstawowym parametrem limitującym ilość ścieków kierowanych na pola jest azot. Z tego względu obniżenie stężenia tego parametru umożliwiłoby skierowanie na pola większej ilości ścieków, przy jednoczesnym spełnieniu norm. W analizowanym zakładzie instalacją redukującą poziom azotu w ściekach jest stacja wyparna. Jednak ze względu na wysokie koszty użytkowania tej instalacji, kierowana jest do niej tylko niewielka ilość najbardziej zanieczyszczonych ścieków. Zamiana gazu ziemnego, wykorzystywanego do wytworzenia pary zasilającej stację wyparną, na biomasę uprawianą na własnych polach rolniczego wykorzystania pozwoli na obniżenie kosztów użytkowania stacji wyparnej. Efektem czego będzie możliwość zwiększenia produkcji oraz utrzymanie poziomu emisji ditlenku węgla. Praca przedstawia rozwiązanie pozwalające na wzrost produkcji na poziomie $70 \%$, przy utrzymaniu poziomu emisji ditlenku węgla.

Słowa kluczowe: wzrost produkcji, odnawialne źródła energii, inżynieria środowiska, oczyszczanie ścieków technologicznych, drożdże, ochrona środowiska

Editor received the manuscript: 30.06 .2015 
PUSTA 